\title{
Composition and diversity of Osyris L. (Santalales Santalacae) communities in the Tlemcen region
}

\author{
Ibrahim Benmechta ${ }^{*}$, Rédda Aboura' \& Brahim Babali' \\ ${ }^{1}$ Laboratory of Ecology and Management of Natural Ecosystems BP119, Department of Ecology and Environment, \\ Faculty of Nature and Life Sciences and Earth and Universe Sciences University of Tlemcen, 13000 Algeria \\ *Corresponding author, email: brahimben6@yahoo.com
}

\begin{abstract}
The region of Tlemcen has a very rich and diverse flora heritage thanks to its geological and climatic variations. The genus Osyris L. (Santalales Santalaceae) is a semi-parasitic species which remains continually subject to host plants that are not well known in our study area. Our main objective was to search for this species, to inventory the taxa which enter into the structuring of its populations in the Tlemcen region and then to characterize them systematically, biologically and biogeographically. The bioclimatic approach of the stations studied shows a lower semi-arid bioclimatic stage which has an influence on the floristic procession of these stands dominated by therophytes. The floristic inventory carried out enabled us, above all, to identify certain host plants specific to the presence of this genus with its two species Osyris alba L. and O. lanceolata, Ochst et Steud. in the Tlemcen region. This presence obeys specific ecological conditions which will give a certain distribution that we will detail in our next work.
\end{abstract}

KEY WORDS Osyris; ecology; diversity; Tlemcen, Algeria.

Received 19.01.2021; accepted 13.04.2021; published online 28.05.2021

\section{INTRODUCTION}

Parasitic plants include over 4000 species of hemiparasites or holoparasites in the angiosperm group (Press \& Phoenix, 2005). Although most can potentially attack a large number of different species (Nilsson \& Svensson 1997; Westbury 2004), some also show a high level of host preference.

The genus Osyris L. (Santalales Santalaceae) is a very branchy tree or shrub with yellow flowers, evergreen and semi-parasitic of the Santalaceae family which consists mainly of root parasites, comprising 35 genera which include nearly 400 species (Bhatnagar, 1991). It is represented by eight species, three of which seem to be distributed in the world, including Osyris alba L. and O. lanceolata, Ochst et Steud. (SIUC, 2005).

Two species Osyris alba and O. lanceolata were reported by Quézel \& Santa (1962), Castroviejo Bolibar et al. (1997) and Dobignard \& Chatelain (2010-2013). This semi-parasitic plant is present in the Mediterranean basin in Spain, in the south of France, in the north of Morocco and almost everywhere in the north of Algeria and partially in Oranie. The genus Osyris attracts the attention of several international researchers in the field of the photochemical and pharmaceutical industry (Hala et al., 2010; Ragheb, 2011; Senait et al., 2015; Meseret et al., 2019), and its ecological side has been little discussed. We note the work of Qasem (2006) where he was able to identify 23 species par- 
asitized by Osyris alba in Jordan. We therefore tried to address the floristic composition of these stands by trying to notify the host plants attacked by this genus in our region.

\section{MATERIAL AND METHODS}

\section{Study area}

Our study area covers part of western Oran which administratively corresponds to the wilayas (departments) of Tlemcen and Ain Témouchent (Figs. 1-5, Table 1). The choice of stations is nevertheless guided by the presence of Osyris consultation of previous work, as well as field trips have shown us that the Osyris stands occupy little space in Oranie, either in the mountainous regions west of the Tlemcen mountains, or in the coastal areas (Rechgoun in particular). We therefore chose four stations belonging to different zones:

Station 1 (Djebel Fellaoucene): it is located in

\begin{tabular}{|l|l|l|c|}
\hline Stations & Lambert coordinates & Altitude & Exposure \\
\hline Djebel Fellaoucene & $\begin{array}{l}35^{\circ} 00^{\prime} 48,11^{\prime \prime} \text { North } \\
001^{\circ} 41^{\prime} 01,02^{\prime \prime} \text { West }\end{array}$ & $950 \mathrm{~m}$ & North \\
\hline Rechgoun & $\begin{array}{l}35^{\circ} 16^{\prime} 59,02^{\prime \prime} \text { North } \\
001^{\circ} 27^{\prime} 16,63^{\prime \prime} \text { West }\end{array}$ & $18 \mathrm{~m}$ & North \\
\hline Ouled Youcef (Beni snous) & $\begin{array}{l}34^{\circ} 37^{\prime} 29,6^{\prime \prime} \text { North } \\
001^{\circ} 34^{\prime} 59,3^{\prime \prime} \text { West }\end{array}$ & $925 \mathrm{~m}$ & North \\
\hline Gueltet Esefah (Chetouane) & $\begin{array}{l}32^{\circ} 55^{\prime} 06,51^{\prime \prime} \text { North } \\
001^{\circ} 16^{\prime} 41,72^{\prime \prime} \text { West }\end{array}$ & $562 \mathrm{~m}$ & North \\
\hline
\end{tabular}

Table 1. Geographical coordinates of the study stations.

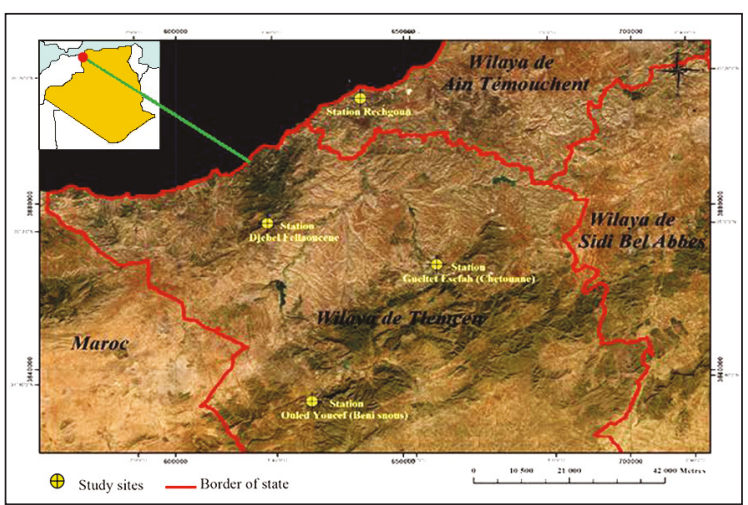

Figure 1. Location of study stations. the Traras mountains to the north-west of the wilaya of Tlemcen, limited by the Tlemcen basin to the south and the seafronts to the north (Ghazaouet).

Station 2 (Rechgoun): it is a coastal resort in the Mediterranean Sea, part of the Wilaya of Ain Témouchent, it is limited to the north by the Mediterranean Sea, to the south by the village of Emir Abdelkader; to the west by the town of Oulhaça and to the east by the village of Sidi Safi.

Station 3 Ouled Youcef (Beni Snous): it is a mountainous station located at an altitude of $925 \mathrm{~m}$ in the west of the Tlemcen mountains.

Station 4 Gueltet Esefah (Chetouane): it is a station located in an agricultural plain on the edge of the Saf-saf wadi, at the foot of the Tlemcen mountains with an altitude oscillating at $562 \mathrm{~m}$.

\section{Climatic variables}

Bary-Lenger et al. (1979) confirm that rain and temperature are the hinge of the climate, they directly influence vegetation (Emberger, 1930, 1971) underlined during his work that the only common denominator making it possible to define the Mediterranean region is above all an ecological order and more particularly a climatic one. It is the natural element over which man has no direct influence except in special cases such as irrigation for example.

The bioclimate corresponding to these Osyris groups is defined by Emberger's Q2 values, the Debrach continentality index, the De Martonne aridity index, the relative seasonal coefficient of Musset and in parallel the ombrothermic diagram of Bagnouls \& Gaussen (1953).

In our case, the climatic parameters taken into account come from three meteorological stations closest to the study region (Ghazaouet, Zenata and Beni-Saf) and this for two periods, the old one (1913-1938) from Seltzer's meteorological collection (1946) and the new period (1992-2016). These stations respectively supervise the study stations considered in this work.

\section{Vegetation}

The study of the plant cover requires an analysis of the plant structure which is itself carried out essentially by the method of floristic surveys accord- 

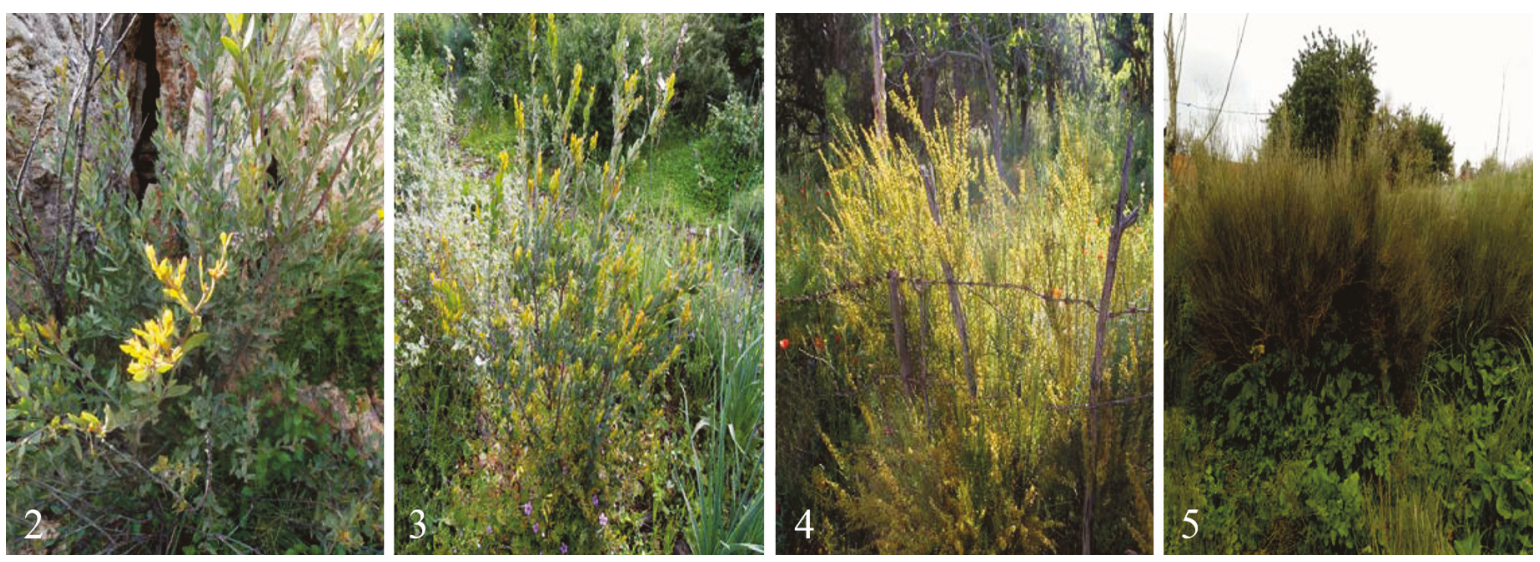

Figures 2-5. Overview of the four study stations. Fig. 2: Djebel Fellaoucene. Fig. 3: Rechgoun. Fig. 4: Ouled Youcef (Beni Snous). Fig. 5: Gueltet Esefah (Chetouane).

ing to Braun-Blanquet (1951) and Guinochet (1973) based on a minimum area equal to $100 \mathrm{~m}^{2}$.

The choice of stations is based on the presence of the genus Osyris in stations at different level of continentality. The work was carried out in the four representative stations which allow us to identify the floristic procession of the genus Osyris by an exhaustive sampling during the good phenological period, which extends from autumn until the beginning of summer from 2017 to 2019, then determine at the same time the host plants parasitized by this genus.

The knowledge of the floristic composition of the study region passes mainly through botanical inventories carried out in the field followed by an identification of each plant species with a systematic, biological and biogeographical characterization from the new flora of Algeria and the southern desert regions (Quézel \& Santa, 1962, 1963). Then a calculation of the disturbance index for each station was performed.

\section{RESULTS}

The comparison from the climatic point of view between the three meteorological stations reveals a long drought duration for all the stations which is 6 to 7 months and a thermal amplitude in the sense of (Debrach, 1953) high between $30^{\circ} \mathrm{C}$ and $36{ }^{\circ} \mathrm{C}$.

The stations of Ghazaouet, Zenata and Beni-saf recorded an average rainfall of between 206.18 $\mathrm{mm} /$ year, $283.16 \mathrm{~mm} /$ year and $361.1 \mathrm{~mm} /$ year. The calculation of Emberger's Q2 and the projection on the pluviothermal climagram of Emberger shows us the bioclimatic situation of the study stations which belong to the lower semi-arid stage with mild winter for the three weather stations. Osyris is therefore well adapted to semi-arid climatic conditions.

\section{Station 1 - Djebel Fellaoucene}

It is a degraded matorral rich in about 146 species; it is dominated by annual species. Osyris lanceolata occurs with 31 tufts, the majority of which are small, it is accompanied by two host species which are Calicotome intermedia and Quercus coccifera. This low density of Osyris lanceolata stands is due to their physiology and edapho-climatic factors, this species occupies the upper part of the slope which has a great maritime influence and it marks its absence at the bottom of the slope.

\section{Station 1 - Rechgoun}

86 species have been inventoried in this station, the majority are therophyte species (41) such as: Hordeum murinum, Erodium moschatum, Ononis pubescens, Medicago minima and a few trees of Quercus ilex and Pinus halepensis. Osyris lanceolata exists within $5.5 \mathrm{~m}$, the accompanying host species are: Rhus pentaphylla, Withania frutescens, Pistacia lentiscus and Calicotome intermedia. 


\section{Station 1 - Ouled Youcef (Beni Snous)}

This station has a very low number of Osyris alba plants, with 13 individuals, which surround Pistacia atlantica which is originally a host plant for this genus. We have identified 30 species, some have a very low presence due to the geographical location of the station which is on a steep slope, we note the presence of an individual for each species of: Anagyris foetida, Amygdalus communis, Ziziphus vulgaris and Ephedra altissima, there are also some annuals such as: Avena sterilis, Aegilops triuncialis, Calendula arvensis and Torilis arvensis.

\section{Station 4 - Gueltet Esefah (Chetouane)}

56 species have been identified. This station is located near wadi Saf-saf, the abundance of Osyris alba is very low $(2.7 \mathrm{~m})$, this species is usually cut because it parasitizes cultivated species like Olea europea. On the other hand, we note the low presence of Salix alba, Populus alba and Asparagus albus as well as a few feet of caesalpinia (Ceratonia siliqua) which are the host plants of Osyris alba in this station. It would also seem that the presence of cereals and grasses such as Hordeum vulgare, Vicia faba, Pisum sativum and Triticum turgidum signifies a high anthropic action which affects this species despite its parasitic physiology.

\section{Systematic composition}

The analysis of the floristic richness of the dif- ferent groups, of their biological and chorological characters would make it possible to highlight their floristic originality, their state of conservation and, consequently, their heritage value (DahmaniMegrerouche, 1997) (Fig. 6).

The floristic inventory at the four stations includes 240 taxa, divided into 60 families of the Angiosperm sub-phylum and some gymnosperms classified in alphabetical order according to the new nomenclature of Dobignard \& Chatelain (2010, 2013).

According to the results of the four stations (Djebel Fellaoucene, Rechgoun, Ouled Youcef and Gueltet Esefah), it was found that the Asteraceae family is predominant in the four stations (between 13 and 23\%), followed by the Fabaceae family ( between 7 and 13\%) and that of Poaceae which marks up to $16.67 \%$ in Ouled Youcef, marking an important diversity.

The rest of the plant families have a very low distribution rate which is distributed among Lamiaceae, Apiaceae, Brassicaceae and Borraginaceae as well as other multispecies families. The genus Osyris and its hosts are represented by the families of Anacardiaceae, Oleaceae and Salicaceae.

\section{Biological characterization}

The biological type of a plant results on the vegetative part of its body, biological mechanisms including those which have been modified by the environment during the life of this plant and are in no way hereditary (Polumin, 1967) (Tables 2, 3).

\begin{tabular}{|l|c|c|c|c|}
\hline Biological types & $\begin{array}{c}\text { Djebel } \\
\text { Fellaoucene }\end{array}$ & Rechgoun & $\begin{array}{c}\text { Ouled Youcef- } \\
\text { Beni snous }\end{array}$ & $\begin{array}{c}\text { Gueltet Esefah- } \\
\text { Chetouane }\end{array}$ \\
\hline Therophytes & $(62) 42.47 \%$ & $(41) 47.67 \%$ & $(14) 46.67 \%$ & $(27) 48.21 \%$ \\
\hline Hemicryptophytes & $(34) 23.29 \%$ & $(7) 8.14 \%$ & $(6) 20 \%$ & $(8) 14.29 \%$ \\
\hline Phanerophytes & $(11) 7.53 \%$ & $(11) 12.8 \%$ & (3) $10 \%$ & (10) $17.86 \%$ \\
\hline Chamephytes & $(28) 19.18 \%$ & $(18) 20.93 \%$ & (5) $16.66 \%$ & (5) $8.93 \%$ \\
\hline Geophytes & $(11) 7.53 \%$ & (9) $10.46 \%$ & (2) $6.67 \%$ & (6) 10.71 \\
\hline Total & (146) $\mathbf{1 0 0} \%$ & (86) $\mathbf{1 0 0 \%}$ & (30) $\mathbf{1 0 0 \%}$ & (56) $\mathbf{1 0 0 \%}$ \\
\hline
\end{tabular}

Table 2. Biological spectrum of the four study stations. 


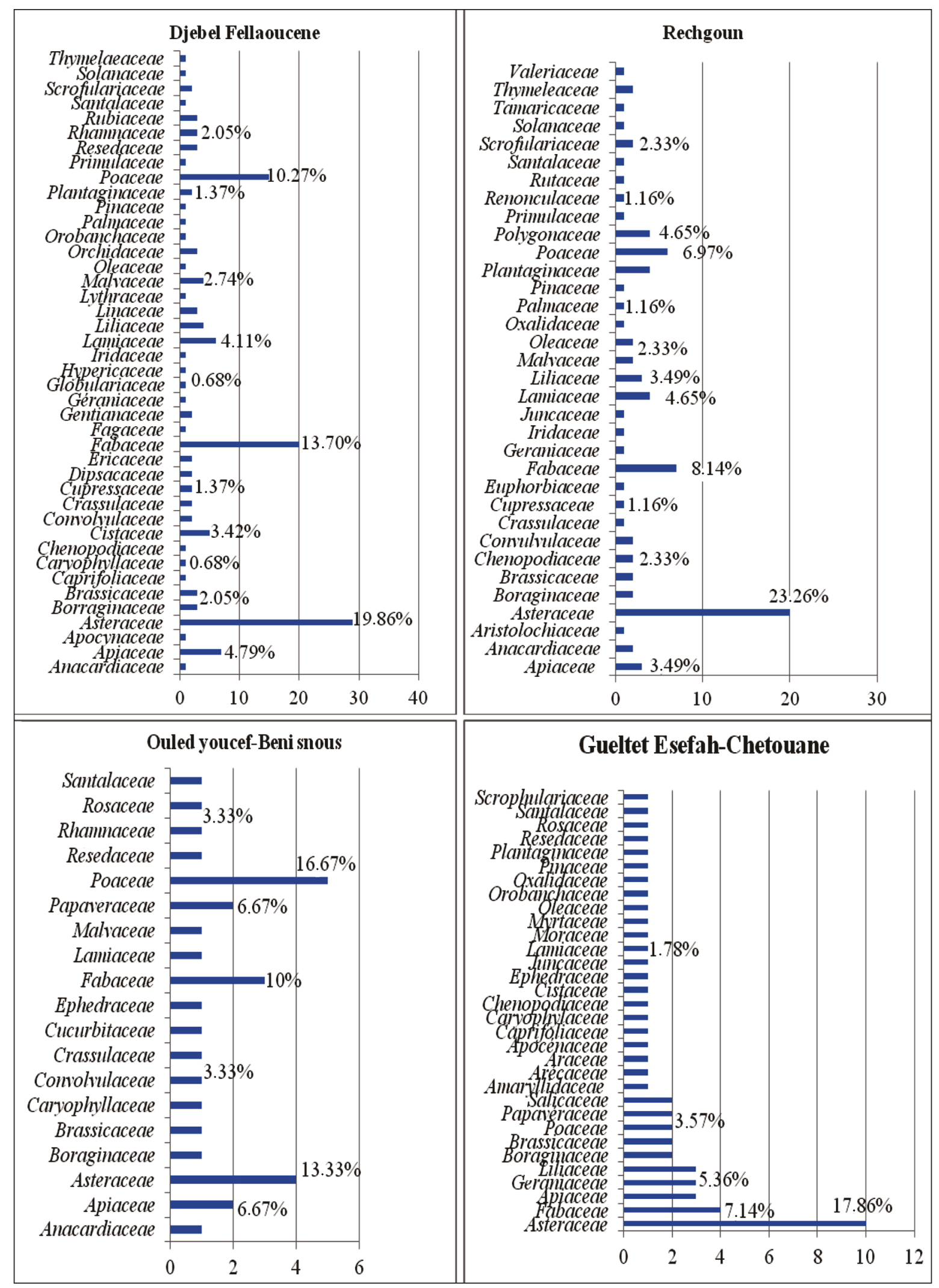

Figure 6. Contribution of the different families (number of species per family) of the four study stations. 


\begin{tabular}{|c|c|}
\hline Station & Disturbance index (\%) \\
\hline Djebel Fellaoucene & 59 \\
\hline Rechgoun & 68 \\
\hline Ouled Youcef (Beni snous) & 63 \\
\hline Geltet Esefah (Chetouane) & 57 \\
\hline
\end{tabular}

Table 3. Disturbance index in the various stations.

Djebel Fellaoucene station: the therophytes are predominant with a percentage of $42.46 \%$ followed by the hemicryptophytes with $23.28 \%$ and the chamaephytes with $19.17 \%$ then the geophytes and the phanerophytes with $7.53 \%$.

Rechgoun station: we notice a strong distribution of therophytes with a percentage of $47.67 \%$ followed by chamaephytes with $20.93 \%$ then a weak recovery by phanerophytes with $12.79 \%$ and geophytes with $10.46 \%$, finally the hemicryptophytes with $8.14 \%$.

Ouled Youcef station (Beni snous): therophytes are predominant with a percentage of $46.67 \%$ followed by hemicryptophytes with $20 \%$ and chamaephytes with $16.67 \%$ and a low rate of phanerophytes (10\%) and geophytes (6.67\%).

Station of Gueltet Esefah (Chetouane): therophytes are predominant with a percentage of $48.21 \%$ followed by phanerophytes with $17.68 \%$ and hemicryptophytes with $14.29 \%$. There is a low percentage of geophytes with $10.71 \%$ and chamaephytes with $8.93 \%$.

In order to be able to assess the state of degradation of the groups, a disturbance index (PI) was calculated for each station, it is defined by Loisel \& Gamila (1993) according to the following report:

\section{IP = Number of Chamaephytes + Number of Therophytes / Total number of species}

The Table 3 shows a variable disturbance index from one station to another, but this difference is not significant. The disturbance index is high in Rechgoun (68\%) and Ouled Youcef (63\%) compared to that of Djebel Fellaoucene (59\%) and Gueltet Esefah (chetouane) (57\%). In this context, (Barbero et al., 1990) report that the disturbances caused by man and his herds are numerous and cor- respond to two increasingly severe situations ranging from matorralisation to desertification via steppization, in addition to the climate of the region of Tlemcen is characterized by a long period of drought (6 to 7 months) hence the abundance of therophytes. Floret \& Pontanier (1982) report that the more an ecosystem is influenced by humans (overgrazing, cultivation), the more important therophytes become. This preponderance of therophytes is jointly linked to seasonal precipitation and by human action and the fires that characterize the forests of the Mediterranean area.

This is also explained by the climatic rigors that the study region is currently experiencing and the structural instability of the soil favoring the development of species with a short life cycle, more or less demanding of water and trophic needs (Stambouli-Meziane, 2010).

\section{Biogeographic types}

Biogeography is the study and understanding of the distribution of living organisms in the light of present and past factors and processes (Hengevel, 1990), it is also a real example to explain episodes of regression (Olivier et al., 1995) (Table 4). The biogeographical characterization of the species inventoried in the four stations shows a biogeographical diversity of the formations in place:

Djebel Fellaoucene station: species of Mediterranean biogeographical origin $(58.9 \%)$ are widespread, followed by multiregional species (28.77\%), then endemic species with a significant rate of $9.59 \%$ including the species Genista atlantica and Genista tricuspidata. Finally, the Nordic species with $2.74 \%$.

Rechgoun station: there is a strong spread of species with a Mediterranean biogeographic area $(62.79 \%)$, which explains the coastal influence on the station which is close to the sea.

Station of Ouled Youcef (Beni snous): there is always a dominance of species with a Mediterranean biogeographic area $(50 \%)$, followed by multiregional (30\%) and northern species (13.33\%). There is a low presence of endemic species $(6.67 \%)$.

Station of Gueltet Esefah (Chetouane): it is dominated by a Mediterranean biogeographic area $(55.36 \%)$, followed by the pluriregional $(28.579 \%)$ and Nordic $(16.07 \%)$ species. We note 


\begin{tabular}{|l|c|c|c|c|}
\hline Chorological types & $\begin{array}{c}\text { Djebel } \\
\text { Fellaoucene }\end{array}$ & Rechgoun & $\begin{array}{c}\text { Ouled youcef- } \\
\text { Beni snous }\end{array}$ & $\begin{array}{c}\text { Gueltet Esefah- } \\
\text { Chetouane }\end{array}$ \\
\hline Mediterranean & $(86) 58.9 \%$ & $(54) 62.79 \%$ & $(15) 50 \%$ & $(31) 55.36 \%$ \\
\hline Multi-regional & $(42) 28.77 \%$ & $(24) 27.91 \%$ & $(9) 30 \%$ & $(16) 28.57 \%$ \\
\hline Nordic & $(4) 2.74 \%$ & $(4) 4.65 \%$ & $(4) 13.33 \%$ & (9) $16.07 \%$ \\
\hline Endemic & $(14) 9.59 \%$ & (4) $4.65 \%$ & (2) $6.67 \%$ & (0) $0 \%$ \\
\hline Total & $\mathbf{( 1 4 6 )} \mathbf{1 0 0} \%$ & $\mathbf{( 8 6 )} \mathbf{1 0 0} \mathbf{0 0}$ & $\mathbf{( 3 0 )} \mathbf{1 0 0} \%$ & $\mathbf{( 5 6 )} \mathbf{1 0 0} \%$ \\
\hline
\end{tabular}

Table 4. Phytogeographic spectrum of the four study stations.

the total absence of endemic species in this station, which is subject to anthropization by agricultural activities.

This biogeographical diversity of the stations studied contributes to the diversity and the richness of the phytogenetic potential of the Osyris stands.

\section{DISCUSSION}

This work allowed us to better understand the groups in Osyris in the region of Tlemcen (western Algeria). The bioclimatic approach has shown the existence of a decreasing pluviometric gradient in the region of Tlemcen where there is a semi-arid climate less than mild winter which can be considered as a factor of reduction of the floristic diversity of groups with Osyris the latter evolve in their entirety and diversity in a geo-systemic model in a position of confrontation between two antagonistic bioclimatic areas: in Ouled Youcef (Beni Snous) and Gueltet Esefah (Chetouane) with continental influences where Osyris alba settles; in Rechgoun and Djebel Fellaoucene with a coastal influence where Osyris lanceolata settles.

The floristic study carried out on the four stations allowed us to advance in the process of recognition and comparison between the Osyris stands of the different stations. Overall, the Asteraceae dominate with around $18 \%$ of the families of the species recorded, the Poaceae and the Fabaceae with around $10 \%$ then co-dominate the floristic inventories of the four study stations.
The calculation of the disturbance index and the comparison of the biological distribution established in the four study stations shows a predominance of therophytes over the other biological forms with $46.26 \%$, which confirms an anthropogenic pressure proportional to the species therophytics in the stations studied. In this regard, therophytization is linked to the invasion of annual species, disseminated by herds especially in the stations of Rechgoun and Djebel Felaoucene. Floret et al. (1992) report that the more a system is influenced by humans (overgrazing, cultivation), the more important therophytes become, also Barbero et al. (1981) explain the therophytization by the final stage of degradation of ecosystems with sub-nitrophilic species linked to overgrazing. In our region, the combined pressures exerted on the Osyris formations undoubtedly lead to a modification in the biological structure of the study stations.

Sauvage (1960), Gaussen (1963), Nègre (1966), Daget (1980) and Barbero et al. (1990) present therophytes as a form of drought resistance. In this regard, Quézel (2000) points out that one of the reasons likely to account for the flora richness in the Mediterranean region is undoubtedly its richness in therophytes. On the other hand, we report a poverty of phanerophytes which are generally host plants of the genus Osyris due to agricultural activities in the stations of Rechgoun, Ouled Youcef and Gueltet Esefah as well as the high frequency of fires in the Djebel Fellaoucene station, the record of which is very rich with 146 species, the majority of which are therophytes. 
Borsali (2013) underlined that the opening up of environments by fires leads to an increase in flora richness.

From a chorological point of view, the percentage of taxa with a Mediterranean distribution is quite high and between 50 and $62 \%$ for all four study stations. Quézel (2000) explains the importance of the biogeographical diversity of Mediterranean Africa by the climatic changes severely undergone in this region since the Miocene, leading to migrations of tropical flora. This same author Quézel (2000) stressed that a phytogeographic study constitutes an essential basis for any attempt to conserve biodiversity. The circum-Mediterranean region therefore appears globally as a major center of differentiation of plant species (Quézel \& Médail, 1995).

Overall, our study has clearly shown that the Osyris lanceolata species present in the two stations with maritime influence is hemiparasitic on the roots of various trees or shrubs such as Calicotome intermedia, Quercus coccifera, Rhus pentaphylla, Withania frutescens and Pistacia lentiscus. On the other hand, the species Osyris alba present in the two mainland stations is hemiparasitic on the roots of Pistacia atlantica, Salix alba, Populus alba, Asparagus albus and Olea europaea.

\section{CONCLUSIONS}

The phylogenetic potential of our region is undergoing a regressive evolution accentuated by an increasingly strong anthropozoogenic pressure combined with a relative change in the climate of western Algeria, especially over the last thirty years. The interest that we should show in these Osyris formations is confirmed by the poor condition of its stands and by their semi-parasitic physiology. The drought that has persisted in Algeria for several years and the increase in forest fires that are devastating several hundred thousand hectares in the Mediterranean region (Pausas \& Vallejov, 1999) make them vulnerable and sensitive to all environmental disturbances. The degraded floristic processions bear witness to the biotic and abiotic conditions, in particular in the four stations. This pioneering ecological study on these stands at Osyris allowed us to come out with very interesting pre- liminary conclusions and deserves to be continued and deepened to have more details on this genus in our study region.

\section{REFERENCES}

Bagnouls F. \& Gaussen H., 1953. Saison sèche et indice xérothermique. Bulletin de la Société d'histoire naturelle de Toulouse, 88: 193-239.

Barbero M., Quézel P. \& Rivas-Martinez S., 1981. Contribution à l'étude des groupements forestiers et préforestiers du Maroc. Phytosocoelogia, 9: 311-412.

Barbero M. Quezel P. \& Loisel R., 1990. Les apports de la phyto-écologie dans 1'interprétation des changements et perturbations induits par l'homme sur les écosystèmes forestiers méditerranéens. Forêt Méditerranéenne, 12: 194-215.

Bary-Lenger A, Evrard R \& Bathy P., 1979. La foret. Vaillant Carmine S. Imprimeur, Liége, 611 pp.

Bhatnagar S.P., 1991. Embryology of the santalaceae. In: Proceedings of the 5th International Symposium of Parasitic Weeds (Nairobi, Kenya, 24-30 June 1991). CIMMYT, Nairobi, 43-45.

Borsali AH., 2013. Contribution à l'évaluation de l'impact des incendies sur les écosystèmes forestiers: cas de la forêt de Fénouane, wilaya de Saïda. (Algérie). Thèse de Doctorat Université Abou Bakr Belkaid Tlemcen \& Université Aix Marseille, France, 237 pp.

Braun-Blanquet J., 1951. Les groupements végétaux de la France méditerranéenne.Centre national de la recherche scientifique Paris, 297 pp.

Castroviejo Bolibar, Santiago \& al. (eds.), 1997. Flora iberica. Plantas vasculares de la Península Ibérica e Islas Baleares. / Editores: S. Castroviejo (Madrid), C. Aedo (Madrid), C. Benedí (Barcelona), M. Laínz (Gijón), F. Muñoz Garmendia (Madrid), G. Nieto Feliner (Madrid) \& J. Paiva (Coimbra); Vol. VIII. Haloragaceae-Euphorbiaceae. Real Jardín Botánico, CSIC, Madrid. Santalaceae, pp. 149-152.

Dahmani-Megrerouche M., 1997. Le chêne vert en Algérie. Syntaxonomie, phytosociologie et dynamique des peuplements. Thèse Doctorat ès-sciences. Université Houari Boumediene. Alger, Algeria, 329 pp. + annexes.

Daget P., 1980. Sur les types biologiques en tant que stratégie adaptative (cas des thérophytes). Recherches d'écologie théorique, les stratégies adaptatives. Maloines, Paris, pp. 89-114.

Debrach J., 1953. Notes sur les climats du Maroc occidental. Maroc médical, 32 (342): 1122-1134.

Dobignard A. \& Chatelain C., 2010-2013. Index synonymique de la Flore d'Afrique du Nord, Éditions des Conservatoire Et Jardin Botanique. Genève, 5 Volumes, pp. 282-283. 
Emberger L., 1930. Sur une formule climatique applicable en géographie botanique. Comptes rendus de l'Académie des Sciences, 191: 389-390.

Emberger L., 1971. Travaux de botanique et d'écologie. Ed. Masson. Paris, 520 pp.

Floret Ch. \& Pontanier R., 1982. L'aridité en Tunisie présaharienne: climat, sol, végétation et aménagement. Paris: ORSTOM, 552 pp. (Travaux et Documents de l'ORSTOM; 150). Th.: Sci.: USTL: Montpellier: 1982/02/04.

Floret C., Le Floc'h E. \& Pontanier K., 1992. Influence de l'évolution de l'occupation de l'espace sur le bilan d'eau régional (Tunisie). In: "L'aridité, une contrainte au développement “E. Le Floc'h, M. @rouais,A . Cornet, J.C. Bille, \&S., Editions ORSTOM, Paris Collection Didactique (s2 paraître).

Gaussen H., 1963. Carte bioclimatique de la zone méditerranéenne. Notice explicative. Edit. UNESCO, $\mathrm{n}^{\circ} 21,60 \mathrm{pp}$.

Guinochet M., 1973. Phytosociologie. Masson Edit. Paris, $227 \mathrm{pp}$.

Hala I. Al-Jaber., Ibrahim M.M., Abdallah M., Omar M. Abu Salim; Musa H. Abu Zarga, 2010. Chemical constituents of Osyris alba and their antiparasitic activities. Journal of Asian Natural Products Research, 12: 814-820.

Hengevel D., 1990. Dynamique Biogéography. Cambridge University Press. Cambridge, 216 pp.

Loisel R. \& Gamila H., 1993. Traduction des effets du débroussaillement sur les écosystèmes forestiers et pré forestiers par indice de perturbation. Ann Soc. Sci. Nat. Archéol. de Toulon du Var: 123-132.

Meseret Y.T., Mohammed B.A. \& Jibril S.Y., 2019. Journal of Evidence-Based Integrative MedicineVolume 24: 1-9. The Author(s) 2019 Article reuse guidelines: sagepub.com/journals-permissions https://doi.org/10.1177/2515690X19833340 journals.sagepub.com/home/cam. Evaluation of In Vivo Antidiarrheal Activity of 80\% Methanolic Leaf Extract of Osyris quadripartita Decne (Santalaceae) in Swiss Albino Mice.

Nègre R., 1966. Les thérophytes. Bulletin de la Société Botanique de France, 113: 92-108. https://doi.org/10.1080/00378941.1966.10838477

Nilsson C.H. \& Svensson B.M. 1997. Host affiliation in two subarctic hemiparasitic plants: Bartsia alpine and Pedicularis lapponica. Ecoscience, 4: 80-85.

Olivier L., Muracciole M. \& Ruderon J.P., 1995. Premier bilan sur la flore des îles de la Méditerranée. Etat des connaissances et observations, diagnostics et proposition relatifs aux flores insulaires de la méditerranée par les participants au colloque d'Ajaccio. Corse. France (5-8 octobre, 1993): 356-358.

Polumin, 1967. Eléments de géographie botanique. Gauthier -villars. Paris, $431 \mathrm{pp}$.
Press M.C. \& Phoenix G.K., 2005. Impact of parasitic plants on natural communities. New Phytologist, 166: 737-751.

Qasem J.R., 2006. Host range of the parasitic weed Osyris alba L. in Jordan. Weed Biology and Management, 6: 74-78. https://doi.org/10.1111/j.1445-6664.2006.00200.x

Quézel P. \& Santa S., 1962. Nouvelle Flore de l'Algérie et des régions désertiques méridionales. Vol. 1. Centre national de la recherche scientifique (CNRS) éditions, Paris, 570 pp.

Quézel P. \& Santa S., 1963. Nouvelle flore de l'Algérie et des régions désertiques méridionales. Vol. 2, Centre national de la recherche scientifique (CNRS) editions, Paris, 600 pp.

Quézel P. \& Medail F., 1995. La région Circumméditerranéenne. Centre Mondial Majeur de Biodiversité Végétale. Inst. Médit. d'Ecologie et de la Paléoécologie, Centre national de la recherche scientifique (CNRS) U.R.A. 1152. Laboratoire de Botanique et d'Ecologie Méditerranéenne. Faculté des Sciences Site St Jérôme Aix Marseille Université, France, pp. 152-155.

Quézel P., 2000. Réflexion sur l'évolution de la flore et de la végétation au Maghreb Méditerranéen. Ibis. Press Edition Paris, 118 pp.

Ragheb J. Qasem, 2011. Department of Plant Protection, Faculty of Agriculture, University of Jordan, Amman, Jordan. Parasitic flowering plants of woody species in Jordan. European Journal of Plant Pathology, 31: 143-155. https://doi.org/10.1007/s10658-011-9794-2

Sauvage C., 1960. Recherches Géobotaniques sur les Subéraies Marocaines. Thèse de Doctorat Es-Sciences naturelles. Facultè des Sciences de Montpellier Uiversité, 414 pp.

Seltzer P., 1946. Le climat de l'Algérie (Alger). La TypoLitho et Jules Carbonel, 1946, 219 pp. Étude publiée avec le concours de A. Lasserre, Mlle A. Grandjean, R. Auberty et A. Fourey - Université d'Alger Travaux de l'Institut de météorologie et de physique du globe de l'Algérie.

Senait G., Mirutse G., Berhanu E. \& Hassen M., 2015. Effect of crude leaf extract of Osyris quadripartita on Plasmodium berghei in Swiss albino mice. BMC Complementary Medicine and Therapies, 15, 184 (2015). https://doi.org/10.1186/s12906-015-0715-3

Southern Illinois University Carbondale (SIUC), 2005. Santalaceae (including Eremolepidaceae), Family description. Available from URL: http://www.parasiticplants.siu.edu/Santalaceae/index. html. Accessed 16 March 2006.

Stambouli-Meziane H., 2010. Contribution à l'étude des groupements psammophytes de la region de Tlemcen. Thèse de Doctorat Écologie Végetale, Départe- 
ment Biologie Faculte Sciences Université Abou Bekr Belkaid Tlemcen, Algerie, 230 pp.

Westbury D.B., 2004. Biological flora of the British isles. http://www.anthos.es/
Rhinanthus minor L. Journal of Ecology, 92: 906927. 